Tala, ZZ. et al. IbM Pemberdayaan Guru Dan Santri Pondok Pesantren Dalam Penanganan...

\title{
IbM PEMBERDAYAAN GURU DAN SANTRI PONDOK PESANTREN DALAM PENANGANAN AWAL PENDERITA LUKA
}

\author{
Zaimah Z. Tala ${ }^{1)}$, Mutiara Indah Sari ${ }^{2)}$, Cut Meliza Zainumi ${ }^{3)}$ \\ Fakultas Kedokteran Universitas Sumatera Utara \\ zaimahclinnut@yahoo.com ${ }^{1)}$, muti_dr@yahoo.com ${ }^{2)}$, zainumi.8@gmail.com ${ }^{3)}$
}

\begin{abstract}
Abstrak
Luka adalah suatu kondisi yang menyebabkan kerusakan atau hilangnya sebahagian jaringan tubuh disebabkan berbagai kemungkinan. Pada keadaan luka dapat terjadi perdarahan hebat, kesakitan yang luar biasa sehingga menyebabkan shok, kehilangan volume cairan tubuh bahkan terjadinya henti jantung. Penatalaksanaan awal segera penderita luka sangat diperlukan orang-orang terdekat penderita untuk mencegah kesakitan yang lebih parah bahkan kematian. Khalayak pondok pesantren yang mempunyai syarat mukim selama aktifitas kesehariannya di pondok sangat mungkin mengalami hal-hal yang menyebabkan luka.. Tujuan pengabdian masyarakat ini adalah meningkatan pengetahuan dan ketrampilan khalayak pondok khususnya para guru dan santri pesantren Kwala Madu Binjai dan Ibadurrahman Stabat dalam penanganan awal penderita luka. Kegiatan pengabdian masyarakat dilakukan pada bulan Juni-Oktober 2017 dengan metode 1) Peninjauan lokasi daerah mitra, 2) Analisa masalah dengan wawancara beberapa guru dan santri mengenai pemahaman penatalaksanaan awal terhadap luka, 3) Penyusunan materi penyuluhan serta teknik pelatihan berdasarkan analisa wawancara, 4) Pelaksanaan penyuluhan dan pelatihan, 5) Evaluasi hasil kegiatan penyuluhan dan pelatihan, 6) Penyerahan bahan dan alat kesehatan yang dibutuhkan dalam penatalaksanaan awal terhadap luka ke pengelola Pesantren. Hasil pengabdian kepada masyarakat ini adalah peningkatan pengetahuan dan ketrampilan guru dan santri dalam penatalakasanaan awal terhadap luka Juga tersedianya bahan dan alat kesehatan yang dibutuhkan dalam penatalaksanaan awal terhadap luka untuk dipergunakan di pesantren
\end{abstract}

Kata kunci: pesantren, penanganan awal, luka

\begin{abstract}
Injury is a condition that causes damage or loss of body tissue which is caused by various possibilities. Injury can occur severe bleeding, extreme pain so that caused shock, loss of interstitial fluid volume and even causing the heart to stop beating.First aid from the nearest patient is urgently needed to prevent more severe illness even death. Whenevery student do their daily activities, they can be injured anytime. The purpose of community service is increasing the knowledge and skills of injury patient's first aidin the Pesantren environtment especially teachers and students of Pesantren Kwala Madu Binjai and Pesantren Ibadurrahman Stabat. Community service activities conducted in June-October 2017 by doing:1) Locations Review, 2) Problem Analysis through interviews with some teachers and students about understanding the first aid of injury, 3) Preparation of thecounselling materials and training techniques based on analysis of the interview results,4) Implementation of counselling and training, 5) Evaluation of counselling and training activities,6) Distribution of necessary medical supplies and equipment to the manager that needed for the first aid of injury. The result of this community service is the improvement of knowledge and skills of teachers and students in the first aid of injury and also the availability of materials and medical equipment needed in the first aid of injury in both Pesantren.
\end{abstract}

Keyword: pesantren, first aid, injury 


\section{PENDAHULUAN}

Luka adalah suatu kondisi yang menyebabkan kerusakan atau hilangnya sebagaian jaringan tubuh yang bisa disebabkan berbagai kemungkinan seperti trauma benda tajam, terjatuh, perubahan suhu, paparan zat kimia tertentu, gigitan hewab, sengatan listrik dan lainnya (Keast and Orsted, 2007). Pada keadaan luka dapat terjadi perdarahan hebat, kesakitan yang luar biasa sehingga menyebabkan shok, kehilangan volume cairan tubuh yang hebat bahkan terjadinya henti jantung. (Sudoyo, 2007). Diperlukan penanganan awal sesegera mungkin untuk menghindarkan penderita jatuh pada kondisi kesakitan yang makin berat bahkan menghindarkan kematian. Wilde (2009) telah membuktikan secara jelas tentang pentingnya waktu tanggap (response time) bahkan pada pasien selain penderita penyakit jantung.

Khalayak pondok sangat mungkin mengalami hal hal yang menyebakan luka. Diperlukan kemampuan dan empati dari setiap individu di lingkungan pondok untuk mau terlibat dalam penanganan awal terhadap siapapun penderita luka baik khalayak dalam pondok maupun luar pondok agar kesakitan yang luar biasa bahkan kematian akibat luka tersebut dapat dicegah

Berdasarkan wawancara awal pada beberapa santri didapatkan data bahwa santrisantri tersebut deficit pengetahuan mengenai penanganan awal pada luka . Berdasarkan data yang didapat dari salah satu guru belum pernah ada kegiatan penyuluhan dan pelatihan ketrampilan terkait materi penanganan awal pada penderita luka khususnya yang terjadi di dalam lingkungan pondok. Baik para guru, santri dan peneglola pondok sangat ingin meningkatkan pengetahuan, ketrampilan dalam penangan awal terhadap penderita luka baik bagi khalayak yang berada di pondok bahkan untuk masyarakat diluar pondok tetapi belum mempunyai kesempatan mendapatkan hal tersebut

Berdasarkan pasal 4 dan 9 UndangUndang No 36 Tahun 2009 diketahui pelayanan kesehatan sehari-hari adalah hak asasi setiap orang serta juga merupakan kewajiban yang harus dimiliki oleh semua orang. Pasal 14 dari UU No 36 ini menyatakan pemerintah dan segenap masyarakat bertanggungjawab dalam memelihara dan meningkatkan kualitas pelayanan kesehatan
(UU No 36/2009). Terjemahan dari pasalpasal di atas dapat diartikan pelayanan kesehatan termasuk penaganan awal penderita luka tidak saja merupakan kemampuan wajib yang dilakukan tenga kesehatan di rumah sakit, tetapi juga akan melibatkan pelayanan pra rumah sakit dalam hal ini masyawakat khalayak yang melakukan mukim di pondok pesantren.

Tujuan pengabdian masyarakat ini peningkatan pengetahuan dan ketrampilan khalayak pondok khususnya para guru dan santri pondok untuk memperberdayakannya dalam penanganan awal penderita luka yang mungkin terjadi dilingkungan pondok bahkan pada masyarakat diluar pondok

\section{PERMASALAHAN}

Setiap orang mempunyai hak dan tanggung jawab terhadap keselamatan diri dan masyarakat. Oleh karena itu setiap orang berhak dan wajib mempunyai pemahaman dan ketrampilan dasar untuk penanganan awal keselamatan diri. Santri, guru dan pengelola pondok pesantren Kwala Madu Binjai dan Ibadurrahman Stabat dalam menjalani aktifitas yang ringan maupun berat kesehariaannya dapat mengalami perlukaan tanpa disengaja.

Dari analisis situasi secara umum permasalahan pada mitra adalah bagaimana meningkatkan pemahaman dan ketrampilan guru dan santri pondok pesantren Kwala madu Binjai dan Ibadurrahman sehingga dapat diberdayakan dalam penanganan awal pada penderita luka. Secara khusus permasalahan pada Pondok Pesantren Muhammadiyah Kwala Madu Binjai dan Pondok Pesantren Ibadurrahman Stabat sebagai mitra pada pengabdiaan masyarakat ini adalah :

a. Pada pondok pesantren Kwala Madu Binjai terdapat suatu ruangan berfungsi sebagai poliklinik khusus bagi khalayak pondok, tetapi alat dan obat-obatan khusus untuk penaganan awal pada keadaan luka serius tidak dijumpai

b. Pada pondok pesantren Ibadurrahman Stabat tidak terdapat ruangan khusus yang berfungsi sebagai poliklinik kesehatan

c. Klinik swasta terdekat dari pondok pesantren Ibadurrahman berjarak $15 \mathrm{~km}$ dan rumah sakit terdekat dari pondok pesantren Kwala madu berjarak $20 \mathrm{~km}$

d. Pengetahuan/ pemahaman guru dan santri Pondok Pesantren Muhammadiyah Kwala 
Nasution, SKH. et al. Development Training Employers' Group Bamboo
Madu Binjai dan Ibadurrahman Stabat mengenai penanganan awal terhadap penderita luka di sangat minim
e. Tidak diketahui bagaimana ketrampilan para guru, santri ataupun pengelola
dan prasarana kesenatan yang ada di kedua mitra. Di analisa seberapa jauh klinik pelayanan kesehatan terdekat yang dapat dijangkau oleh kedua mitra untuk mendapatkan pelayanan kesehatan pondok dalam penanganan awal penderita luka

f. Belum pernah ada penyuluhan dan pelatihan mengenai penanganan awal terhadapat luka pada khalayak kedua pondok

g. Pihak pesantren menginginkan adanya pihak yang berkompeten membantu mereka untuk memahami dan memiliki ketrampilan dalam penanganan awal penderita luka

\section{METODE}

Kegiatan pengabdian dilakukan dengan beberapa tahapan secara terintegrasi dengan mitra.Tahapan pengabdian ini adalah:

Tahap 1: Peninjauan
lokasi daerah mitra

Tahap 2: Analisa masalah: wawancara guru dan santri mengenai pemahaman penatalaksanaan awal terhadap luka

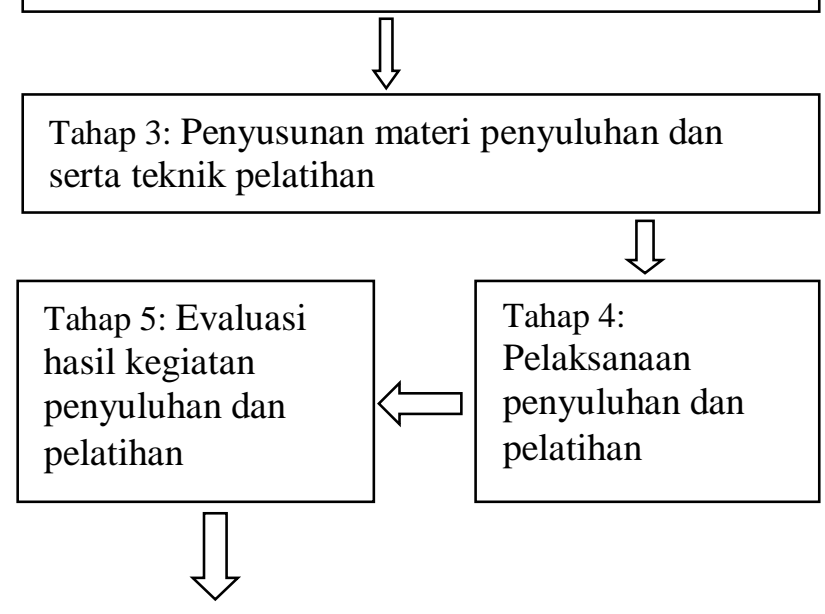

Tahap 6. Penyerahan bahan dan alat kesehatan yang dibutuhkan dalam penatalaksanaan awal terhadap luka ke pengelola Pesantren

dilakukan mulai bulan Juni 2017 sampai Oktober 2017 secara bertahap. dengan hasil:

\section{Peninjauan lokasi daerah mitra}

Peninjauan ke lokasi mitra di lakukan sebelum mengajukan proposal pengabdian masyarakat. Pada tahapan ini dinilai sarana

\section{Wawancara pada beberapa guru dan santri}

Pada tahapan ini penulis melakukan tanya jawab mengenai pengetahuan guru dan santri terhadap jenis luka, hal-hal yang terjadi yang menimbulkan perlukaan pada guru dan santri selama mukim di pesantren, seberapa sering kejadian yang menimbulkan perlukaan terjadi di lingkungan pesantren dan bagaimana penanganan awal yang selama ini dilakukan terhadap kondisi tersebut

\section{Penyusunan materi penyuluhan dan serta teknik pelatihan}

Materi untuk kegiatan penyuluhan disusun berdasarkan hasil wawancara, meliputi:

1. Jenis-jenis luka berdasarkan penyebab

2. Komplikasi yang terjadi akibat luka

3. Penanganan awal terhadap luka

Metode penyuluhan berupa:

1. Pemaparan materi dengan LCD dan alat peraga oleh narasumber/ tim pengusul

2. Tanya jawab

Kegiatan pelatihan dilakukan dengan cara

1. Demonstrasi penanganan awal terhadap luka oleh narasumber/ tim pengusul dengan dibantu instruktur menggunakan manikin serta bahan dan alat kesehatan berupa (Franz et al, 2010)
a. Pembersihan luka pada luka robek
b. Pembalutan luka
c. Pembidaian luka

2. Pelatihan perkelompok terhadap guru

3. Pelatihan perkelompok terhadap santri

4. Guru dan santri mencoba melakukan penanganan awal terhadap luka pada manikin

Pondok Pesantren Muhammadiyah Kwala Madu Binjai merupakan pondok pesantren mandiri yang didirikan sejak tahun 1988 terletak di jalan Tanjung Pura Km 32 Binjai. Jumlah santri di pondok tahun 2017 ini 540 orang dan jumlah pengajar serta tenaga administrasi, dan pengelola pondok lainnya sebanyak 78 orang. Pondok Pesantren Ibadurrahman Stabat adalah pesantren yang 
Nasution, SKH. et al. Development Training Employers' Group Bamboo

dibangun oleh pendirinya Ir. Muklis terletak di jalan UDKP Paya Mabar Stabat. Pada tahun ajaran 2017 ini terdata ada 478 santri rincian santri pria sebanyak 275 orang dan santri putri 203 orang yang sedang menjalani pendidikan.

Sesuai dengan penyebutan pondok yang dilekatkan di depan nama pesantren ini maka setiap santri dikenakan syarat wajib mukim sampai selesai menjalani pendidikan, masing masing selama 3 tahun untuk tingkat Tsanawiyah dan 3 tahun berikutnya untuk tingkat Aliyah (Zamakhasyari, 1983). Diperlukan fasilitas yang lengkap bagi khalayak dalam pondok sehingga terjamin lancarnya proses belajar dan mengajar. Selain fasilitas untuk proses belajar mengajar dibutuhkan juga fasilitas untuk peningkatan kualitas kesehatan khalayak pondok seperti Fasilitas untuk peningkatan kualitas kesehatan dapat berupa ketrampilan pengelola pesantren, guru dan santri serta tersedianya prasarana dan sarana klinik kesehatan.

Penyuluhan mengenai penanganan awal penderita luka diberikan kepada guru-guru dan masing-masing 100 orang santri Aliyah dari kelas 1,2 dan 3 santri di kedua pondok. Beberapa pertanyaan yang muncul pada saat pelaksanaan penyuluhan yang diajukan oleh guru dan santri adalah:

1. Apa yang dilakukan sebaiknya pertama sekali dilakukan jika ada luka yang mengeluarkan darah, membersihkan luka atau menghentikan luka

2. Apa yang harus dilakukan jika terjadi darah yang keluar terus menerus akibat luka

3. Mengapa sewaktu tertusuk sesuatu pada telapak kaki yang awalnya terjadinya luka akibat tuudkan tersebut tidak menegluarkan darah hanya tersaa sakit dan sedikit bengkak beberapa hari kemudian tempat terjadinya tusukan bernanah dan menyebabkan demam

4. Bagaimana jika terjadi luka gigitan akibat perkelahian

Tim pengusul memberi penjelasan terhadap pertanyaan-pertanyaan selama penyuluhan berlangsung yaitu:

1. Prinsip awal penatalaksanaan luka adalah menghentikan pendarahan, bisa dengan cara membalut tekan luka, terutama pada luka besar. Bila perdarahan sudah berhenti baru luka bisa dibersihkan.
2. Luka dapat dibalut tekan dengan menggunakan kasa atau kain yang steril. Luka terlalu besar atau perdarahan terus menerus maka harus ditangani segera ke puskesmas atau rumah sakit

3. Nanah terjadi akibat luka tidak dibersihkan dengan baik. Setelah luka dibersihkan dengan air yang steril, dapat diberikan antiseptic atau salep antibiotik. Hati-hati pada luka tusuk, misalnya paku, karena dapat menyebabkan tetanus.

4. Penatalaksanaan luka gigitan sama seperti luka lainnya. Stop perdarahan bila ada, bersihkan luka, beri antiseptik, bila perlu tutup luka.

Pelaksanaan pelatihan ketrampilan penanganan awal pada luka diikuti oleh guru dan santri dengan antusias. Tim pengusul yang merupakan narasumber langsung pada kegiatan ini menperagakan bagaimana teknik teknik membersihkan luka, menghentikan berdarahan, pembalutan pada luka serta melakukan peragaan pembidaian jika terjadi luka patah

\section{Evaluasi hasil kegiatan penyuluhan dan pelatihan}

Setelah melakukan penyuluhan dan beberapa kali pelatihan penanganan awal terhadap luka pada guru dan santri di kedua pesantren tim pengusul kembali datang ke pesantren untuk melakukan evaluasi hasil kegiatanan. Evaluasi dilakukan dengan cara diskusi materi penyuluhan yang sudah diberikan dan meminta guru dan santri secara acak melakukan peragaan penagnan awal pada beberpa jenis luka. Hasil evaluasi menunjukkan terjadi peningkatan pengetahuan dan ketrampilan guru dan santri dikedua pondok pesantren terhadap penangan awal terhadap luka

\section{Penyerahan bahan dan alat kesehatan untuk fasilitas pesantren}

Dalam program ini di tim pengusul menyerahkan bahan dan alat kesehatan yang diperlukan dan dapat dipergunaka oleh pesantren untuk penatalaksanaan awal terhadap luka baik jika terjadi pada khalayak di dalam lingkungan pesantren.

Pengetahuan dan ketrampilan yang diperoleh oleh guru dan santri dikedua pondok pesantren diharapkan juga digunakan untuk 
Nasution, SKH. et al. Development Training Employers' Group Bamboo

menolong khalayak di luar pesantren/ masyarakat yang tinggal di sekitar pesantren

\section{KESIMPULAN DAN SARAN}

\section{Kesimpulan}

Setelah pelaksanaan pengabdian masyarakat penanganan awal pada luka berupa penyuluhan dan pelatihan diperoleh:

1. Peningkatan pengetahuan guru dan santri mengenai jenis-jenis luka, komplikasi luka dan penanganan awal terhadap luka

2. Peningkatan ketrampilan guru dan santri terhadap penanganan awal pada luka

3. Tersedianya bahan dan alat sebagai sarana untuk meningkatkan kualitas kesehatan bagi guru dan santri khusunya dalam hal penanganan luka

\section{Saran}

1. Perlu dilakukan penyegaran secara berkelanjutan bagi guru dan santri dalam pemberian materi mengenai kesehatan khususnya mengenai penanganan awal pada luka

2. Perlu dilakukan pelatihan lebih intensif bagi para guru dan santri sehingga bisa lebih trampil dalam menangani luka

\section{UCAPAN TERIMAKASIH}

Ucapan Terimakasih Kepada Lembaga Pengabdian Pada Masyarakat Universitas Sumatera Utara Yang Telah Menfasilitasi Pelaksanaan Pengabdian Masyarakat IbM Mono Tahun ini dengan No Kontrak 3221/UN5.2.3.2.1/PPM/2017 pelaksanaan tahun 2017

\section{DAFTAR PUSTAKA}

Franz, M. G. Wound Healing In Doherty, G. M. Current Diagnosis \& Treatment. Surgery. 2010. Ed. 13. New York : Mc. Graw HillLange,

Keast, D., Orsted, H. 2007. The Basic Principles of Wound Healing. Avalaible at : // www.pilonidal.org/pdfs/Mei2017

Sudoyo, Aru, W., Bambang, S., Idrus, A., Marcellus S., 2007. Buku Ajar Ilmu Penyakit dalam jilid I. Edisi IV.Pusat Penerbit Fakultas Kedokteran Indonesia. Jakarta. Hal 180-181

Undang-Undang No 36 tahun 2009 . Tentang Kesehatan

Wilde, E. T.2009. Do Emergency Medical System Response Times Matter for Health Outcomes?.New York: Columbia University Zamakhsyari Dhofier. 1983. Tradisi Pesantren Studi tentang Pandangan Hidup. LP3S, Jakarta. Hal 1 